\section{King George VI Sound}

ONE of the most important discoveries of Mr. J. Rymill's recent British Graham Land Expedition was the discovery of the remarkable narrow sound which appears to separate Alexander Island from the main Antarctic continent and to extend for some two hundred and fifty miles in a north and south direction. The Times announces that this feature, by permission of the King, has been named King George VI Sound. It would appear to make not only a physiographical but also a structural division, since the rocks to the east are volcanic while those to the west, in Alexander Island, are fossiliferous sedimentaries which are probably related to the rocks of the Andean folds of Graham Land in general.

\section{A Large Sunspot}

A BRIEF scrutiny of the sun's disk on January 15, made possible at Greenwich in a break of persistent cloud, showed that a big sunspot had appeared. The approximate time of the central meridian passage was January $18 \cdot 4$, the latitude of the spot being $19^{\circ} \mathrm{N}$. ; its area was estimated to be about 2,500 millionths of the sun's hemisphere. The spot, which resembles the giant spot of last October, will reach the sun's western limb on January 24. A magnetic storm was recorded at Abinger commencing on January 16 at $22 \cdot 6^{\mathrm{h}}$.

\section{Dr. H, L. A. Tarr}

DR. H. L. A. TARR, of the Rothamsted Experimental Station, has been appointed to the Sir William Dunn Institute of Pathology, University of Oxford, where he will carry out research on the chemistry of the bacteria responsible for certain human diseases. During the past four years he has been in charge of the investigations on the brood diseases of bees at Rothamsted and accounts of his work have appeared regularly in the various English bee journals and in scientific periodicals. Dr. Tarr went to Rothamsted early in 1934 with a considerable and varied previous experience in bacteriological work. He had been connected with the Department of Dairy Bacteriology at the University of British Columbia and the Departments of Pathology and Industrial and Cellulose Chemistry of McGill University in Canada, and, immediately before taking up his position at Rothamsted, worked for three years under Sir Gowland Hopkins in the Sir William Dunn Institute of Biochemistry, Cambridge.

\section{New Sundials at the Science Museum}

Two portable sundials of considerable interest have recently been acquired and placed on exhibition in the Time Measurement Section of the Science Museum. The first is an ivory column or 'pillar' dial dated 1587, designed for use in a latitude of $44^{\circ}$ and indicating hours on the old Italian system in which the day-and-night period was divided into 24 equal parts, starting from sunset. The second dial is a 'universal' one, adjustable for use over a wide range of latitudes; it is by Dollond, the well-known eighteenth century London maker, and has been presented to the Museum by Mr. J. Bentley Bennett.

\section{Announcements}

The Right Hon. Neville Chamberlain, M.P., Prime Minister; the Rev. M. E. Aubrey, general secretary of the Baptist Union; and Viscount Nuffield, chairman of Morris Motors, Ltd., have been elected members of the Athenæum under the provisions of Rule II of the Club, which empowers the annual election by the Committee of a certain number of persons of distinguished eminence in science, literature, the arts, or for their public services.

Dr. P. LewIS-DaLE, chief chemist of the L.M.S. Railway, has retired; he is succeeded by Mr. W. P. Henderson, assistant chief chemist (Horwich). Mr. H. Hayhurst succeeds Mr. Henderson as chief chemist of the research department at Horwich.

Dr. C. G. Seligman, emeritus professor of ethnology in the University of London, is leaving in a few days for Yale University, where he will occupy the post of Bishop Museum visiting professor for the second semester of the present academic year. $\mathrm{He}$ will lecture on New Guinea, particularly that part (now called Papua) which used to be known as British New Guinea. Dr. Seligman will be at Yale until early in June, and his address will be: Hall of Graduate Studies, Yale University, Newhaven, Conn., U.S.A.

DR. F. M. R. WALSHE has succeeded Dr. Gordon Holmes as editor of Brain.

A short course on industrial physiology and medical industrial psychology will be held at the London School of Hygiene, Keppel Street, W.C.I, on February 7-18. It is designed for members of the supervisory staff in industry, but may also be of interest to industrial medical officers. Further information can be obtained from the Secretary of the School.

THE seventh International Congress of Genetics will be held in Edinburgh in 1939, probably on August 23-30. Prof. F. A. E. Crew, Institute of Animal Genetics, University of Edinburgh, Edinburgh, 9, has been appointed general secretary to the Congress and to him all correspondence concerning it should be addressed.

THE Ducheune de Boulogne Academy, which aims at rewarding independent workers in honour of the memory of the celebrated neurologist, has recently awarded its annual prize of 10,000 francs to Dr. Louis Bory for his work on general, experimental and comparative pathology, the chemotherapy of sulphur, and dermato-syphiligraphy. Further information about the prize can be obtained from the Secretary of the Academy, 28 bis rue Saint-Dominique, Centre Marcellin-Berthelot, Paris. 